\title{
PERANCANGAN DATABASE SISTEM PENJUALAN MENGGUNAKAN DELPHI DAN MICROSOFT SQL SERVER
}

\author{
ASEP ASADILLAH \\ 785567939 \\ University Of Mitra Indonesia \\ Asepasadillah.student@umitra.ac.id
}

\begin{abstract}
Abstrak
Sistem penjualan pada CV. Angin Timur Seafoods masih menggunakan sistem penjualan manual sehingga memunculkan beberapa permasalahan pada prosedur penjualan manual yang diterapkan. Oleh karena itu diusulkan suatu perancangan database sistem penjualan terkomputerisasi dengan menggunakan Microsoft $S Q L$ Server dan Delphi, agar dapat memberikan solusi atas permasalahan yang muncul.Hasil perancangan ini adalah database sistem penjualan dapat memudahkan perusahaan dalam memenuhi kebutuhan informasi yang cepat,tepat dan akurat, serta memberikan solusi atas permasalahan yang ada.Perancangan sistem ini sudah memenuhi kebutuhan informasi dan kondisi perusahaan.
\end{abstract}

Kata kunci: Sistem Penjualan, Perancangan Database Sistem Penjualan, Delphi, SQL Server 


\section{INTRODUCTION}

\section{PENDAHULUAN}

Perkembangan teknologi komputer yang semakin meningkat dapat mempermudah perusahaan dalam menghasilkan suatu informasi yang cepat, tepat dan akurat. Teknologi komputer yang digunakan dalam pengolahan data akuntansi yang sering diterapkan saat ini adalah penggunaan software-software akuntansi atau aplikasi akuntansi. Dengan adanya software dan aplikasi tersebut dapat membantu perusahaan dalam pengolahan data secara terkomputerisasi sehingga data yang diolah tersistematis dan terhindar dari resiko human error.

Tujuan sistem sistem informasi akuntansi itu sendiri untuk menyediakan informasi bagi pengelolaan kegiatan usaha, untuk memperbaiki informasi (improve information) yang dihasilkan oleh sistem yang sudah ada, untuk memperbaiki pengendalian akuntansi dan pengecekan intern (improve internal check), dan untuk mengurangi biaya klerikal (improve clerical cost) dalam penyelenggaraan catatan akuntansi (Mulyadi, 2001:19).

CV. Angin Timur Seafoods menggunakan aplikasi penjualan secara manual sehingga memunculkan suatu permasalahaan dari penerapan sistem penjualan manualnya yaitu hasil dokumen transaksi penjualan berupa arsip penjualan dapat menimbulkan kesalahan atas pencatatan nominal atau angka dan nota terselip, dalam proses update persediaan barang, karyawan masih melakukan sistem manual dan tidak ter-update secara otomatis, permasalahan dalam proses peninjauan tagihan penjualan kredit yaitu dengan jumlah pelanggan yang banyak karyawan mengalami kesulitan dalam proses pengecekan jangka waktu kredit per pelanggan, hal tersebut dikarenakan pencatatan penjualan kredit masih menggunakan sistem manual. Sehingga karyawan harus mengecek satu per satu atas nota penjualan kreditnya.

Dari permasalahan yang muncul tersebut dibutuhkan prosedur penjualan secara terkomputerisasi agar lebih memudahkan proses transaksi dan proses pembuatan laporan penjualan dalam periode harian, bulanan, serta tahunan. Karena pada CV. Angin Timur Seafoods ini masih belum menerapkan sistem pengarsipan data 


\section{Manual Books Article Task}

transaksi penjualan yang disimpan dalam database sistem.Berdasarkan latarbelakang permasalahan yang ada pada CV. Angin Timur Seafoods maka dibuatlah suatu rumusan masalah yaitu untuk melakukan perancang sistem database penjualan pada CV. Angin Timur Seafoods.

\section{LITERATURE REVIEW}

\section{KONSEP SISTEM INFORMASI AKUNTANSI PENJUALAN}

Bagian ini menjelaskan mengenai teori yang berhubungan dengan sistem informasi akuntansi penjualan dan perancangan database sistem penjualan.

\subsection{Sistem Informasi AkuntansiPenjualan}

Menurut Bagranoff (2010) menyatakan bahwa sistem informasi akuntansi adalah sebuah pengumpulan data dan memproses prosedur untuk menciptakan informasi yang dibutuhkan oleh kebutuhan penggunanya.Sistem penjualan merupakan salah satu komponen sistem informasi akuntansi, sistem penjualan terbagi dua yaitu penjualan tunai dan kredit.Terdapat beberapa fungsi yang berperan penting dalam sistem penjualan, yaitu:

Tabel 1. Tabel Fungsi Bagian Sistem Penjualan

\begin{tabular}{cll}
\hline & \multicolumn{1}{c}{$\begin{array}{c}\text { Sistem Penjualan Tunai } \\
(\text { Krismiaji, 2005:281) }\end{array}$} & \multicolumn{1}{c}{$\begin{array}{c}\text { Sistem Penjualan Kredit } \\
(\text { Hall, 2004:175) }\end{array}$} \\
\hline \multirow{4}{*}{ Fungsi Sistem } & Bagian Penjualan & Bagian Penjualan \\
& Bagian Kasir & Bagian Kredit \\
& Bagian Pemegang Buku Jurnal & Bagian Gudang \\
Penjualan & Bagian Buku Besar & Bagian Pengiriman \\
& & Bagian Penagihan \\
& & Bagian Piutang Dagang \\
& & Bagian Buku Besar Umum \\
\hline
\end{tabular}

\subsection{Sistem Pengendalian Internal pada Prosedur Penjualan}

Menurut Romney (2005:30) Di dalam siklus pendapatan, SIA yang didesain dengan baik harus menyediakan pengendalian yang memadai untuk memastikan bahwa tujuan-tujuan berikut ini harus tercapai :

a) Semua transaksi telah diotorisasi dengan benar.

b) Semua transaksi yang dicatat valid (benar-benar terjadi).

c) Semua transaksi yang valid, dan disahkan, telah dicatat.

d) Semua transaksi dicatat secara akurat.

e) Aset (kas, persediaan, dan data) dijaga dari kehilangan ataupun pencurian.

f) Aktivitas bisnis dilaksanakan secara efisien dan efektif.

\subsection{KonsepPerancangan Database Sistem Penjualan}

Database adalah kumpulan data terkait yang biasanya disimpan dalam komputer. Dan file yang berhubungan dan dimanipulasi oleh paket perangkat lunak khusus disebut dengan Sistem Manajemen Database (DBMS). Database termasuk tempat penyimpanan informasi dan file yang terkait untuk sistem persediaan, sistem buku besar, dan sistem penjadwalan produksi (Bagranoff , 2010:116). Dalam melakukan perancangan database melibatkan fungsi penjualan dengan menggambarkan alur proses bisnis perusahaan menggunakan Data Flow Diagram dan Flowchart. Dan konsep Nomalisasi sebagai database server sistem penjualannya. Untuk perancangan output dibutuhkan aplikasi pemrograman yaitu Delphi. Berikut contoh bentuk Normalisasi :

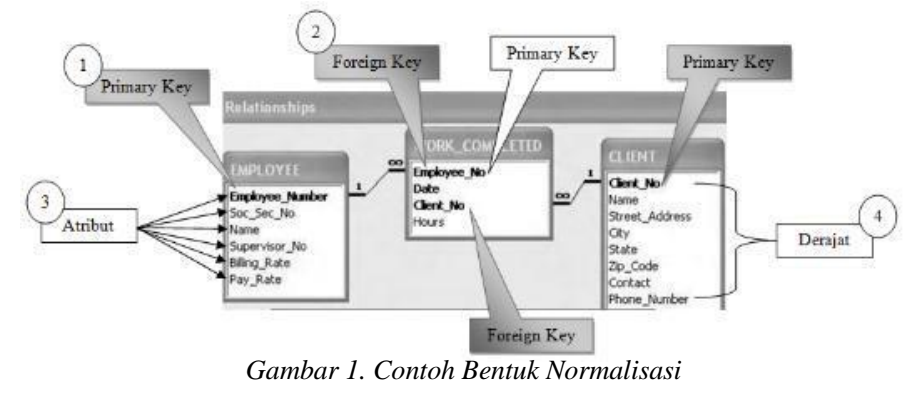

\section{PERANCANGAN DATABASE SISTEM PENJUALAN CV. Angin Timur Seafood}

Dalam tahap perancangan ini dibutuhkan suatu relasi tabel yang berbentuk normalisasi untuk menggambarkan suatu hubungan antara entitasnya. Usulan normalisasi yang digunakan untuk sistem penjualan di PT Seafood. Berikut ini merupakan penjelasan proses perancangan database sistem penjualan dengan teknik dokumentasi 


\section{Manual Books Article Task}

menggunakan data flow diagram (DFD) dan flowchart, serta menggunakan Delphi sebagai bahasa pemrogramannya dan Microsoft SQL Server sebagai database server.

Konsep normaliasasi yang di gunakan dalam penelitian ini adalah bentuk normal ketiga (3NF/Third Normal Form). Konsep normal ketiga menyaratkan bahwa relasi harus sudah berada dalam bentuk normal kedua dan tidak mengandung dependensi transitif. Agar suatu relasi masuk kedalam bentuk normal ketiga, dependensi transitif harus dibuang

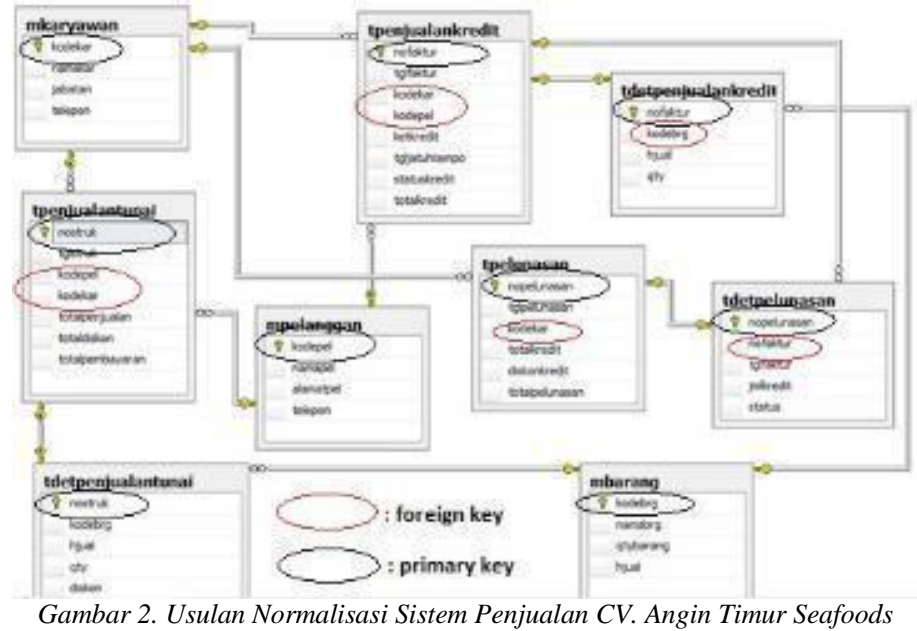

Gambar tersebut merupakan tahap pembuatan desain database menggunakan teknik normalisasinya dengan menggunakan SQL Server, dari gambar tersebut terdapat keterangan bahwa primary key ada di setiap tabel dan foreign key terdapat pada beberapa tabel. Karena foreign key tersebut berfungsi sebagai identitas utama untuk data yang diambil dari tabel laiinya, agar antara tabel tersebut dapat berhubungan dan tidak memunculkan adanya redudansi data.

\subsection{Usulan Data Flow Diagram Sistem Penjualan CV. Angin Timur Seafoods}
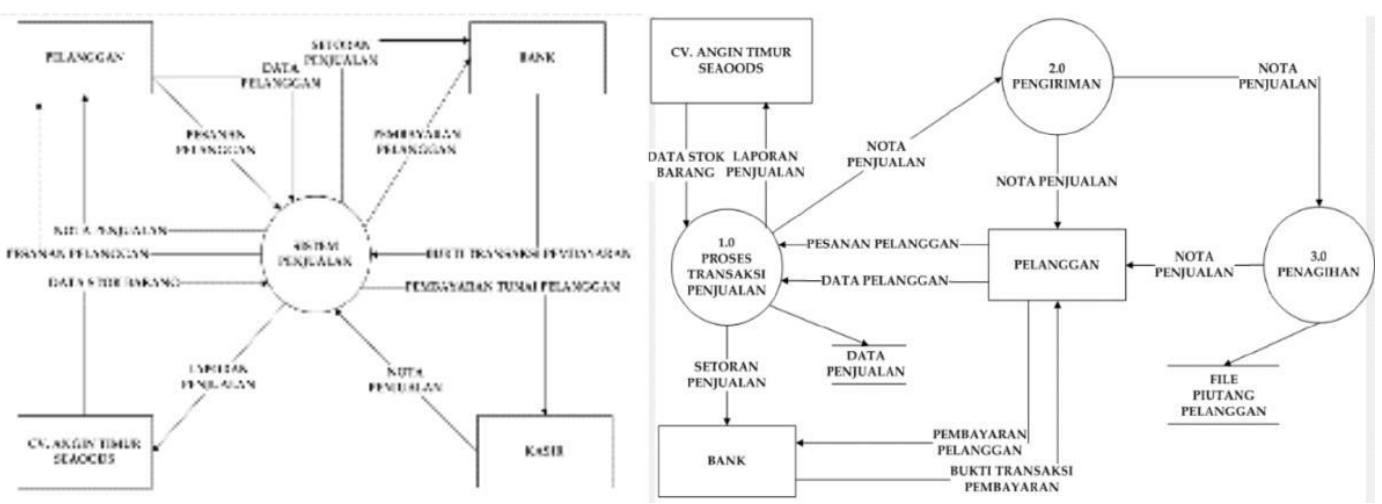

Gambar 3. DFD Konteks dan DFD Level 0 
Manual Books Article Task

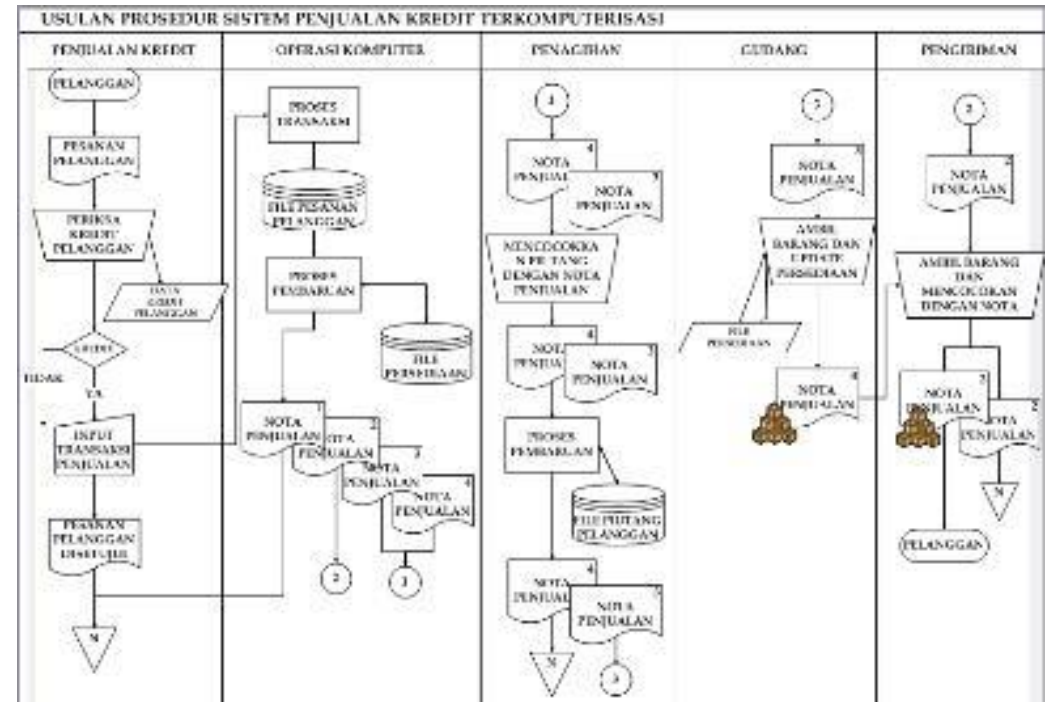

Gambar 4. Usulan Flowchart Sistem Penjualan Kredit Terkomputerisasi

3.2 Usulan Flowchart Sistem Penjualan CV. Angin Timur Seafoods

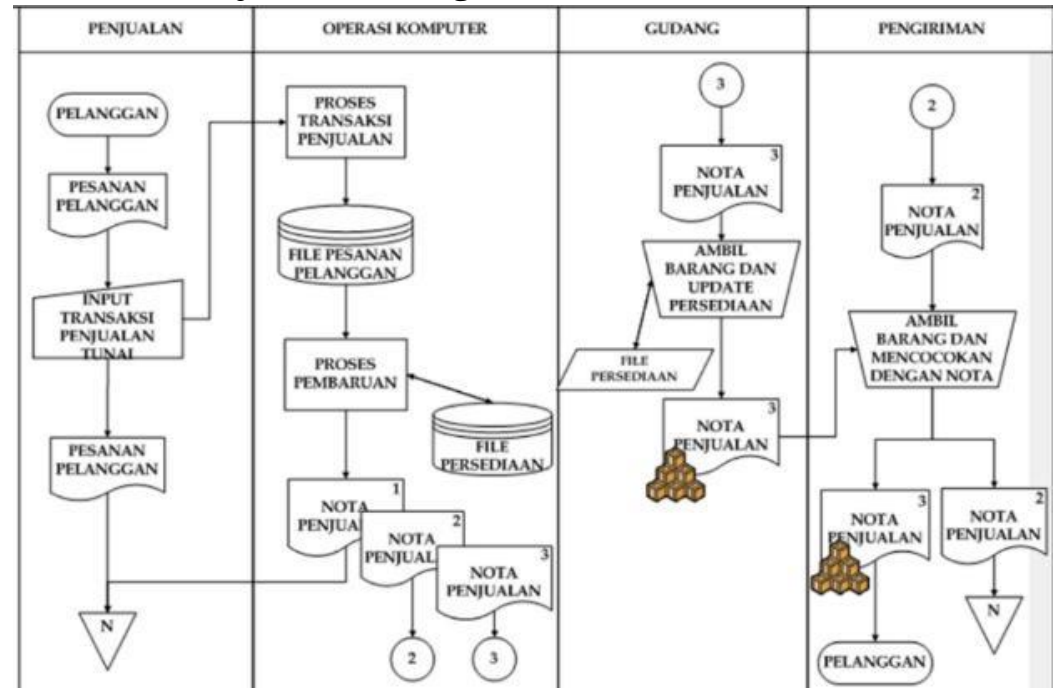

Gambar 5. Usulan Flowchart Sistem Penjualan Tunai Terkomputerisasi

\section{RESULT}

\subsection{Perancangan Input}

\subsubsection{DesainForm Transaksi Penjualan Tunai}

Untuk proses input transaksi penjualan tunai dapat dilakukan pada form Transaksi Penjualan Tunai. Berikut merupakan tampilan desain form Transaksi Penjualan Tunai.

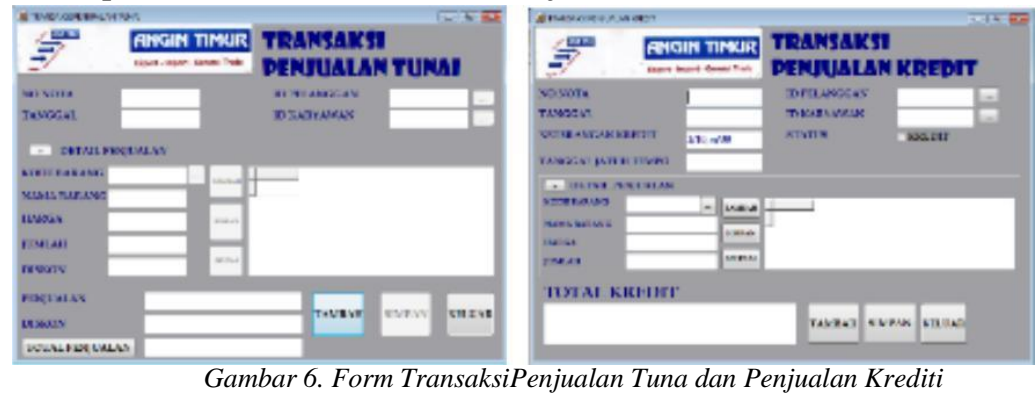




\section{Manual Books Article Task}

\subsubsection{DesainForm Transaksi Plunasan Piutang Pelanggan}

Untuk proses input transaksi pelunasan merupakan desain form yang dibuat untuk memperbarui piutang pelanggan yang telah dilunasi. Transaksi tersebut dapat dilakukan pada form Transaksi Pelunasan. Berikut merupakan tampilan desain form Transaksi Pelunasan.

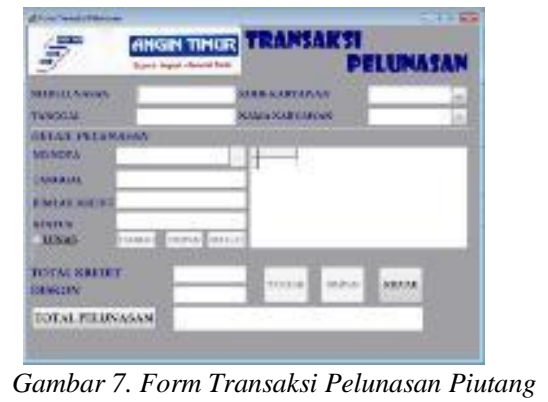

\subsubsection{DesainInput Laporan Piutang Pelanggan Per Hari}

Desain laporan ini dibuat untuk menghasilkan sebuah laporan piutang pelanggan per tanggal yang diinput. Adapun desain input untuk laporan piutang per hari yaitu sebagai berikut.

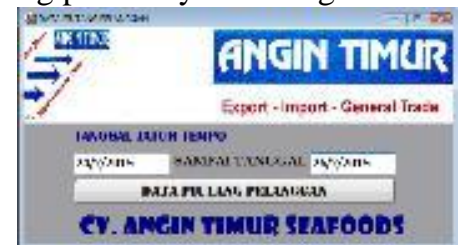

Gambar 8. Form Desain Input Laporan Piutang Pelanggan per Hari

\subsection{Perancangan Output}

\subsubsection{Desain Laporan Transaksi Penjualan Tunai}

Untuk desain laporan transaksi penjualan tunai menghasilkan sebuah nota penjualan yang tercetak berdasarkan nomor nota yang diinput. Berikut merupakan output dari data transaksi penjualan tunai.

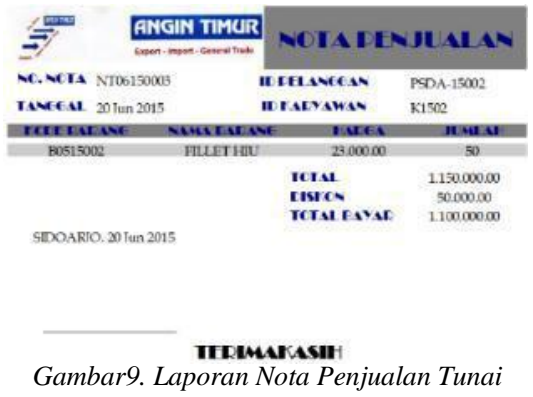

\subsubsection{Desain Laporan Transaksi Penjualan Kredit}

Untuk desain laporan transaksi penjualan kredit menghasilkan sebuah nota penjualan yang tercetak berdasarkan nomor nota yang diinput. Berikut merupakan output dari data transaksi penjualan kredit.

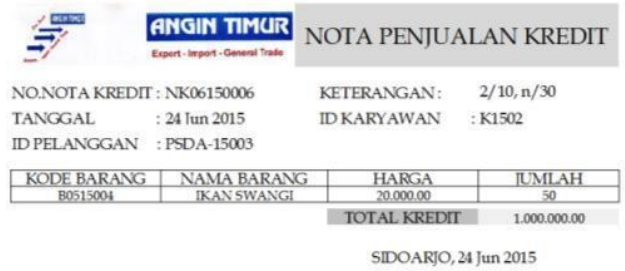

Gambar10. Laporan Nota Penjualan Tunai dam Nota Penjualan Kredit

\subsubsection{Desain Laporan Transaksi Pelunasan Piutang}

Untuk desain laporan transaksi pelunasan menghasilkan sebuah nota pelunasan yang tercetak berdasarkan nomor pelunasan dan nomor nota kredit yang dilunasi. Berikut merupakan output dari data transaksi pelunasan. 


\section{Manual Books Article Task}

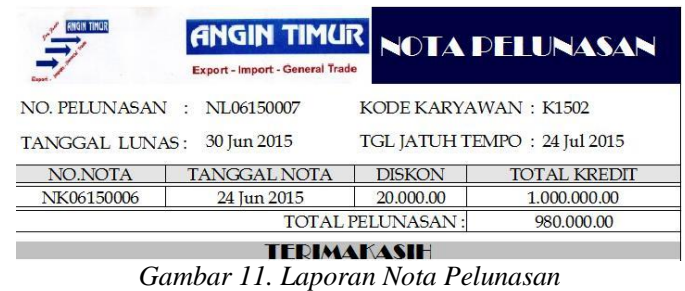

\subsubsection{Desain Laporan Piutang Pelanggan per Tanggal}

Desain laporan piutang pelanggan dapat memudahkan perusahaan untuk meninjau piutang pelanggan per tanggal jatuh temponya. Data piutang pelanggan berasal dari transaksi penjualan kredit yang memiliki status 'kredit'.

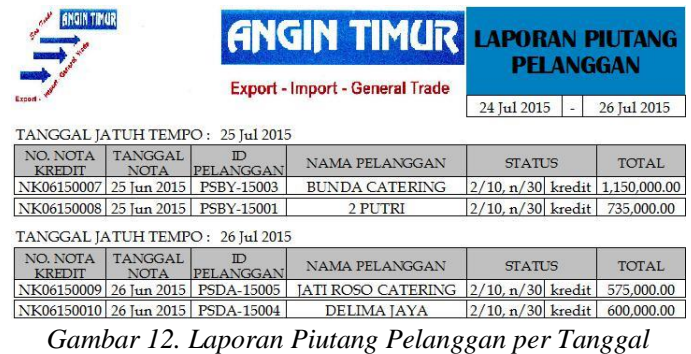

\section{Temuan}

\section{Analisis Perbandingan Sistem Penjualan}

Analisis perbandingan sistem ini bertujuan untuk membandingkan sistem penjualan yang sedang berjalan dan usulan sistem yang dibuat, agar dapat mengetahui hasil yang didapat dari usulan perancangan sistem penjualan tersebut.

Tabel 2. Tabel Perbandingan Sistem Berjalan dengan Usulan Sistem Penjualan Terkomputerisasi

\begin{tabular}{l}
$\begin{array}{c}\text { Prosedur Penjualan yang sedang } \\
\text { Berjalan }\end{array}$ \\
\hline Proses transaksi penjualan \\
menggunakan sistem manual dan \\
dokumen hasil transaksi penjualan \\
hanya berupa arsip penjualan yang \\
dapat memunculkan kesalahan atas \\
pencatatan angka atau nominal dan \\
resiko nota penjualan terselip.
\end{tabular}

Pada saat proses memperbarui
persediaan barang, karyawan
masih melakukan sistem manual
sehingga informasi persediaan
barang yang telah terjual tidak ter-
update secara otomatis.

Dalam membuat laporan penjualannya perusahaan ini masih menerapkan sistem manual sehingga membutuhkan waktu yang lama dalam proses penyusunan laporan penjualannya. Dalam melakukan update piutang pelanggan, karyawan harus menelusuri piutangnya secara manual satu per satu. Sehingga membutuhkan waktu yang lama jika dilakukan secara manual.

\section{Usulan Sistem Penjualan}

Proses transaksi penjualan yang telah terkomputerisasi dapat menhasilkan suatu sistem transaksi penjualan yang secara otomatis tersimpan dalam database yang telah dirancang.
Hasil dari Usulan Sistem Penjualan

Dengan adanya sistem database penjualan, hasil dokumen transaksi penjualan dapat tersimpan secara aman, dapat mengurangi kesalahan atas pencatatan nominal atau angka, serta terhindar dari resiko kehilangan data.

Dalam proses memperbarui stok Dengan adanya sistem persediaan barang, database penjualan database, dapat mempermudah akan secara otomatis mengurangi perusahaan dalam proses barang yang telah terjual. memperbarui stok persediaannya dan membuat proses update persediaan lebih efektif.

Dengan adanya sistem database, laporan penjualan dapat langsung dicetak. Karena ketika melakukan proses transaksi penjualan, secara otomatis dapat memperbarui file penjualannya.

Untuk proses update piutang pelanggan akan secara otomatis diperbarui dengan sistem database penjualan. Sehingga karyawan dapat langsung melihat piutang per pelanggan.
Informasi yang dihasilkan dari sistem database lebih cepat, tepat dan akurat. Sehingga dapat memudahkan perusahaan dalam menyajikan informasi untuk pihak manajemen.

Dengan adanya sistem database ini dapat memudahkan karyawan dalam mengecek dan memperbarui piutang pelanggannya secara otomatis. 


\section{Manual Books Article Task}

\section{CONCLUSION}

\subsection{Simpulan}

Dengan adanya sistem penjualan terkomputerisasi pada CV. Angin Timur Seafoods, semua tugas karyawan telah tersusun secara sistematis dan mudah untuk dioperasikan tanpa harus melakukan proses manual dalam bertransaksi. Selain dapat memudahkan perusahaan, perancangan ini dapat mengurangi kesalahan proses transaksi yang disebabkan oleh faktor human error. Dengan adanya sistem database penjualan ini semua file tersimpan secara aman di harddisk komputer sehingga dapat terhindar dari resiko perangkat lunak (seperti virus atau kehilangan data) karena komputer telah terlindungi oleh Antivirus yang dapat mem-backup semua data. Waktu yang dibutuhkan dalam proses transaksi pun lebih cepat dan hasilnya lebih akurat dibandingkan dengan menggunakan proses manual.Dan laporan yang dihasilkan dari aplikasi transaksi tersebut dapat membatu perusahaan dalam menyajikan informasi yang berkualitas.

\section{ACKNOWLEDGEMENT}

University Of Indonesia University Of Mitra Indonesia Telkom University University Of Mellbourne Saitama University

\section{REFERENCES}

2. A. S. Putra, H. Sukri, and K.

Zuhri,"SistemMonitoring

Realtime Jaringan Irigasi Desa

(JIDES)DenganKonsep

Jaringan Sensor Nirkabel,"

IJEIS (Indonesian J. Electron. Instrum. Syst., vol. 8, no. 2, pp. 221-232.

3. D. P. Sari, O. M. Febriani, and A.

Putra, "Perancangan Sistem

Informasi SDM Berprestasi pada

SD Global Surya," in Prosiding Seminar Nasional Darmajaya, 2018, vol. 1, no. 1, pp. 289-294.

4. A. S. Putra, "Paperplain:

Execution Fundamental Create Application With Borland Delphi 7.0 University Of Mitra Indonesia," 2018.

5. A. S. Putra, D. R. Aryanti, and I.

Hartati, "Metode SAW (Simple

Additive Weighting) sebagai Sistem Pendukung Keputusan Guru Berprestasi (Studi Kasus:

SMK Global Surya)," in

Prosiding Seminar Nasional Darmajaya, 2018, vol. 1, no. 1, pp. 85-97.

6. A. S. Putra and O. M. Febriani,

"KnowledgeManagement

Online Application in PDAM

LampungProvince,"in

Prosiding International conference on Information

Technology and Business (ICITB), 2018, pp. 181-187.

7. A. S. Putra, O. M. Febriani, and

Bachry, “Implementasi

Genetic Fuzzy System Untuk Mengidentifikasi Hasil Curian Kendaraan Bermotor Di Polda

Lampung," SIMADA (Jurnal

Sist. Inf. dan Manaj. Basis Data), vol. 1, no. 1, pp. 21-30, 2018.

1. A. S. Putra, "2018 Artikel

Struktur Data, Audit Dan

Jaringan Komputer," 2018.

2. O. M. Febriani and A. S. Putra,

"Sistem Informasi Monitoring

Inventori Barang Pada Balai Riset Standardisasi Industri

Bandar Lampung," J. Inform., vol. 13, no. 1, pp. 90-98, 2014. 
Fakultas Komputer

ASEP ASADILLAH

Manual Books Article Task

Eopyright (C) 2015 SESINDO 